\title{
Teknologi Pemanfaatan Limbah Padat Pengolahan Keripik Singkong Menjadi Pakan Pellet Ayam Pedaging di Desa Baratan Kabupaten Jember
}

Nurul Pratiwi

Fakultas Pertanian, Universitas Jember

Nyu.pratiwi@gmail.com

\begin{abstract}
Abstrak
Desa Baratan, Kecamatan Patrang, Kabupaten Jember memiliki potensi tinggi dalam usaha produksi keripik singkong yang dikelola oleh Industri Rumah Tangga (IRT). Limbah padat berupa kulit singkong yang dihasilkan dari pengolahan singkong menjadi kripik singkong belum termanfaatkan dengan baik. Kulit singkong dapat digunakan sebagai bahan baku pakan ternak. Tujuan dari program ini adalah pemberdayaan masyarakat IRT Desa Baratan dalam pengolahan kulit singkong menjadi pakan pelet ayam pedaging sehingga menambah nilai guna dari limbah tersebut dan mampu meningkatkan ekonomi para pelaku IRT keripik singkong di Desa Baratan. Kulit singkong memiliki kekurangan karena kandungan antrinutrisi (Asam Sianida) yang berbahaya apabia dikonsumsi. Metode yang digunakan dalam program ini yaitu penyuluhan dan percontohan pemotongan singkong dengan alat chipping, penyuluhan dan pelatihan pemanfaatan limbah kulit singkong, penyuluhan dan pelatihan formulasi pakan ayam pedaging, pembuatan pelet, pendampingan, monitoring dan evaluasi. Hasil dari program pengabdian kepada masyarakat ini adalah kelompok IRT Desa Baratan Kabupaten Jember mampu mengolah limbah padat pengolahan keripik singkong menjadi pakan pelet ayam pedaging. Buku panduan dapat digunakan oleh masyarakat dengan baik sehingga IRT dapat mengolah limbah menjadi pakan secara mandiri. IRT keripik singkong selaku mitra program pengabdian ini dapat melaksanakan dan menerapkan teknologi yang telah diberikan dan berusaha untuk selalu kontinu dalam pembuatan pakan serta pengembangan produk pelet sebagai upaya meningkatkan kesejahteraan dan keberlanjutan program.
\end{abstract}

Kata kunci: limbah kulit singkong, pakan, Desa Baratan

\section{PENDAHULUAN}

Kabupaten Jember memiliki beberapa daerah sentra produksi kripik singkong. Kripik singkong merupakan salah satu olahan pangan yang banyak diproduksi dan telah menjadi sumber pendapatan bagi masyarakat desa Baratan, Kecamatan Patrang, Kabupaten Jember. Usaha produksi kripik singkong yang dikelola oleh Industri Rumah Tangga (IRT) di desa Desa Baratan, Kecamatan Patrang, Kabupaten Jember memiliki kapasitas produksi rata-rata mencapai $100 \mathrm{~kg}$ bahan baku/hari dan penghasilan rata-rata mencapai Rp. 300.000 400.000,- per hari. Bahan baku 100 kg singkong menghasilkan limbah sebanyak $10 \mathrm{~kg}$ yang terdiri dari kulit singkong. Limbah kulit singkong di desa baratan tidak dimanfaatkan secara optimal dan biasanya hanya dibuang. Namun, terkadang ada peternak yang mengambil untuk diberikan kepada ternaknya. Pemanfaatkan kulit singkong untuk pakan ternak masih sangat rendah. Hal ini dikarenakan kulit singkong masih mengandung zat beracun (Sandi, 2012) 
yang mengganggu kesehatan ternak apabila dikonsumsi secara berlebihan dan kurang tepat yaitu sekitar 18,0 - 309,4 ppm per 100 gram kulit singkong (Richana, 2013).

Mitra dalam kegiatan program pengabdian ini yaitu gabungan Industri Rumah Tangga (IRT) di desa Baratan Kecamatan Patrangri Kabupaten Jember. Mata pencaharian masyarakat di desa Baratan adalah memproduksi keripik singkong. Limbah yang dihasilkan dari produksi keripik singkong yang berupa limbah padat kulit singkong masih belum termanfaatkan dengan baik. Limbah kulit singkong memiliki kandungan nutrien yang tinggi sebagai sumber karbohidrat sehingga berpotensi sebagai bahan pakan ternak. Namun, kulit singkong memiliki zat antinutrisi yaitu asam sianida (HCN) yang dapat membahayakan ternak apabila terkonsumsi. Kadar $\mathrm{HCN}$ dalam kulit singkong tidak konstan dan dipengaruhi oleh lingkungan.

Strategi yang harus ditempuh untuk menanggulangi kendala yang dihadapi IRT kripik singkong di Desa Baratan tersebut dalam pemanfaatan limbah padat kulit singkong adalah edukasi teknik pengolahan limbah kulit singkong tepat dari segi peningkatan nutrien, nilai guna limbah dan menghilangkan kandungan antrinutrisi HCN. Salah satu cara untuk mengurangi kandungan HCN dan meningkatkan kualitas nutrien limbah kulit singkong yaitu dengan metode fermentasi. Pelatihan pembuatan pakan fermentasi dilakukan untuk memaksimalkan potensi limbah kulit singkong. Nilai guna limbah akan menjadi lebih tinggi baik dalam segi nutrien, kecernaan dan nilai jual sebagai bahan baku pakan ternak. Pelatihan pengolahan limbah padat industri keripik singkong yaitu kilit singkong melalui proses fermentasi menjadi pelet pakan ayam pedaging dilatihkan kepada IRT Desa Baratan, Kabupaten Jember sebagai satu upaya pemberdayaan masyarakat berbasis limbah. Tujuan dari kegiatan ini adalah memberdayakan masyarakat IRT Desa Baratan untuk bisa meningkatkan kesejahteraan dan mampu membuat pelet pakan ayam pedaging dari limbah kulit singkong secara mandiri dan berkelanjutan.

\section{MATERI DAN METODE}

Kegiatan ini dilakukan selama 6 bulan mulai Agustus 2017 - Januari 2018 di IRT Keripik Singkong Desa Baratan, Kecamatan Patrang, Kabupaten Jember, Jawa Timur. Alat yang digunakan pada program ini adalah parutan singkong, mesin pelet, sprayer, ember besar, baskom, timbangan, plastik dan terpal. Bahan yang digunakan yaitu kulit singkong, dedak padi, molasses, dan EM4. Prosedur kerja yang dilakukan untuk proses fermentasi kulit singkong Tahapan awal yang dilakukan dalam proses fermentasi yaitu 1) memisahan kulit luar kulit singkong dengan kulit dalam, 2) Kulit bagian dalam dicuci dan dijemur untuk mengurangi kadar air. 3) menghaluskan kulit dalam singkong 4) mencampur dengan bahan lain yaitu dedak, molases dan EM4, 5) mengaduk sampai tercampur rata, 6) memasukan pada plastik atau ember secara padat dan menghindari adanya kebocoran 7) proses fermentasi dilakukan secara anaerob selama 14-28 hari. Proses pembuatan pelet ayam pedaging yaitu untuk langkah awal yang dilakukan adala 1) mempersiapkan alat dan bahan; 2) Mencampur semua bahan yang telah diformulasikan dengan bahan baku utama yaitu fermentasi kulit singkong sampai tercampur rata; 3) Membiarkan campuran agak mengering; 4) Menggiling dan mencetak pelet; dan 5) Mengeringkan pelet.

Bentuk kegiatan secara keseluruhan dapat dilihat pada Gambar 1.

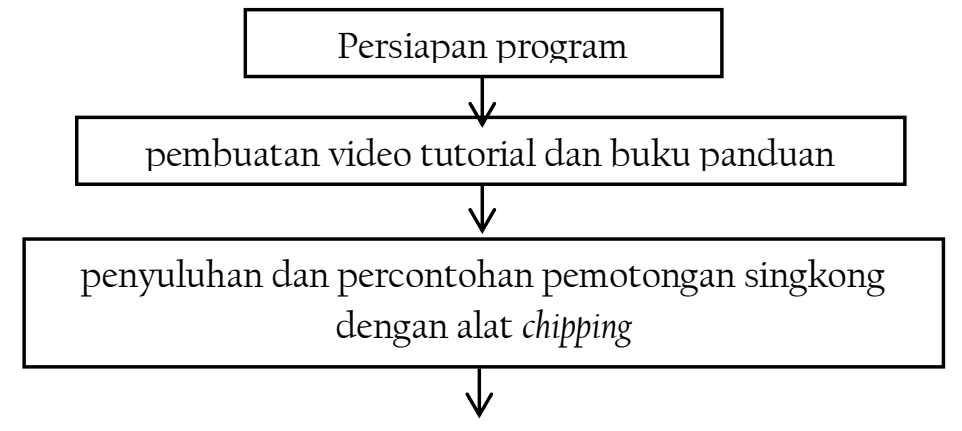




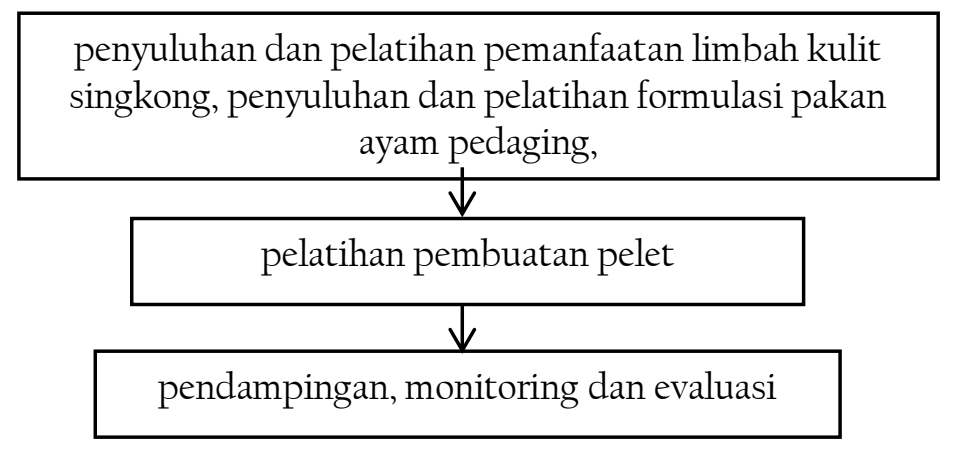

\section{HASIL DAN PEMBAHASAN}

Program pengabdian kepada masyarakat IRT Keripik singkong di Desa Baratan ini dilakukan secara terstruktur dan melibatkan masyarakat secara langsung. Kegiatan ini dilaksanakan pada IRT Keripik singkong sejumlah 20 orang.

\subsection{Teknik pemotongan singkong}

Kegiatan ini dilakukan untuk mengenalkan langsung kepada IRT mengenai cara lebih cepat pemotongan singkong. Kegiatan diawali dengan memberi alat pemotong singkong bermata pisau 4 buah kemudian membandingkan hasilnya dengan menggunakan alat yang biasa IRT gunakan. Kegiatan berlangsung di rumah salah satu IRT keripik singkong.

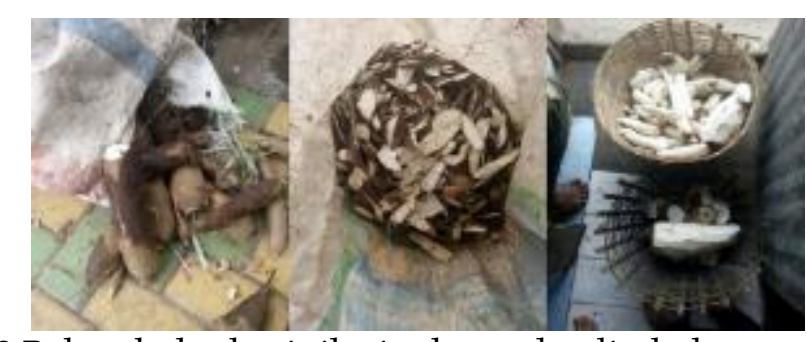

Gambar 2 Bahan baku keripik singkong dan limbah yang dihasilkan

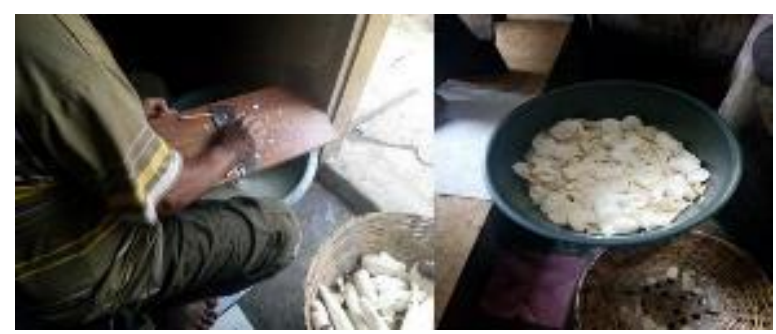

Gambar 3 Alat pemotong singkong tradisional satu mata pisau dan hasil potongannya

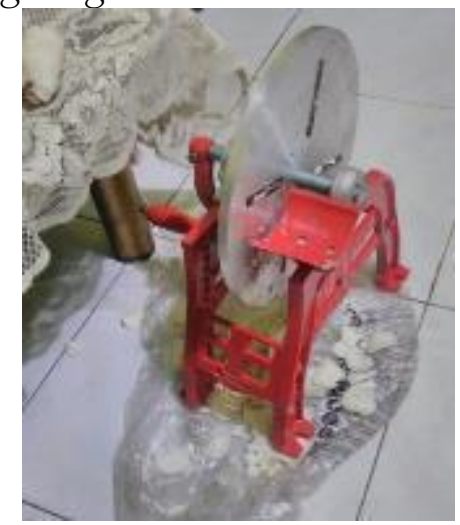


Gambar 4. Alat pemotong singkong dengan 4 mata pisau dan hasil potongannya

Hasil diskusi kegiatan ini diketahui bahwa IRT sebenarnya sudah mengenal alat ini akan tetapi masih terkendala modal untuk membelinya. Penggunaan alat pemotong pisau dengan 4 buah mata pisau dapat mempercepat waktu pemotongan sehingga IRT dapat mengolah limbah kuit singkong menjadi bahan baku pakan yang memiliki nilai jual dan dapat menambah keuntungan bagi IRT. Selama ini, IRT lebih memilih membuang limbah kulit singkong karena keterbatasan kemampuan, tenaga kerja dan waktu dalam mengolahnya menjadi sesuatu yang lebih berguna.

\subsection{Penyuluhan pemanfaatan limbah kulit singkong}

Kegiatan ini dilakukan untuk mengenalkan para IRT dalam memanfaatkan limbah kulit singkong yang dapat diberikan kepada ternak. Kulit singkong memiliki nutrien yang masih dapat dimanfaatkan sebagai pakan ternak. Komposisi nutrien kulit singkong yaitu protein kasar 4,8 \%, Serat Kasar 21,2 \%, dan Energi Metabolis $2960 \mathrm{Kkal} / \mathrm{kg}$ (Akhadiarto, 2010) Kegiatan ini dilakukan dengan cara memberikan penyuluhan dengan menunjukkan video tata cara pengolahan limbah kulit singkong yang diolah dengan teknik fermentasi. Kegiatan ini diharapkan IRT mampu melakukan pengolahan kulit singkong dengan teknik fermentasi.

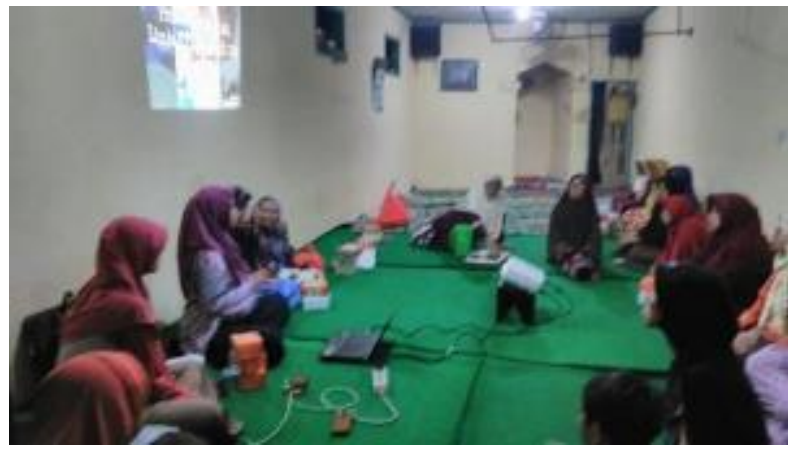

Gambar 5 Pemberian materi pengolahan limbah kulit singkong fermentasi

Potensi kulit singkong dalam penggunaannya sebagai pakan ternak perlu memperhatikan kandungan HCN (Asam sianida). HCN merupakan racun yang dapat mengganggu kesehatan ternak bahkan bisa menyebabkan kematian (Sandi, 2012). HCN memiliki sifat mudah menguap dan kadarnya akan menurun secara bertahap pada suhu dan kelembaban yang tinggi selama penyimpanan (Bradbury and Denton, 2010). Perlakuan proses fermentasi dalam pengolahan pakan akan menurunkan kadar HCN dalam kulit singkong sehingga aman dikonsumsi oleh ternak.

\subsection{Pelatihan dan percontohan secara terstruktur bagaimana cara membuat kulit singkong fermentasi}

Kegiatan diawali dengan memberikan contoh dalam melakukan fermentasi kulit singkong. Tahap awal dilakukan pelatihan yaitu pertama pengumpulan limbah kulit singkong kemudian dilakukan pembersihan dengan memisahkan kulit singkong bagian luar dan dicuci untuk menghilangkan tanah yang masih menempel kemudian dijemur. Setelah dijemur sebentar, kulit singkong bagian dalam digiling. Tahap terakhir adalah perlakuan fermentasi dengan memberikan larutan EM4 yang sudah bercampur dengan air gula sebagai nutrisi bagi pertumbuhan bakteri. Tahap terakhir yaitu dengan perlakuan fermentasi kedap udara dengan memasukkan kulit singkong yang sudah dicampur dengan bahan fermentasi kedalam plastik kedap udara dan disimpan selama 3-4 minggu. Hasil fermentasi dikatakan berhasil apabila tidak terdapat kontaminasi jamur dalam proses fermentasi dan aroma yang 
ditimbulkan berbau asam wangi khas hasil fermentasi.

Mikroba dalam proses fermentasi akan tumbuh dan menghasilkan enzim selulolitik yang akan memecahkan dinding sel kuli singkong (Budiarto, 2011). Mikroba akan menghidrolisis pati ke gula dan mengubahnya menjadi asam organik, terutama asam laktat (Amri dan Pratiwi, 2014). Kandungan nutrien kulit singkong akan meningkat dan kandungan anti nutrien asam sianida akan berkurang dan menghilang selama proses fermentasi. Kadar protein bisa meningkat menjadi 40,86\% dan karbohidrat 49,58\%.

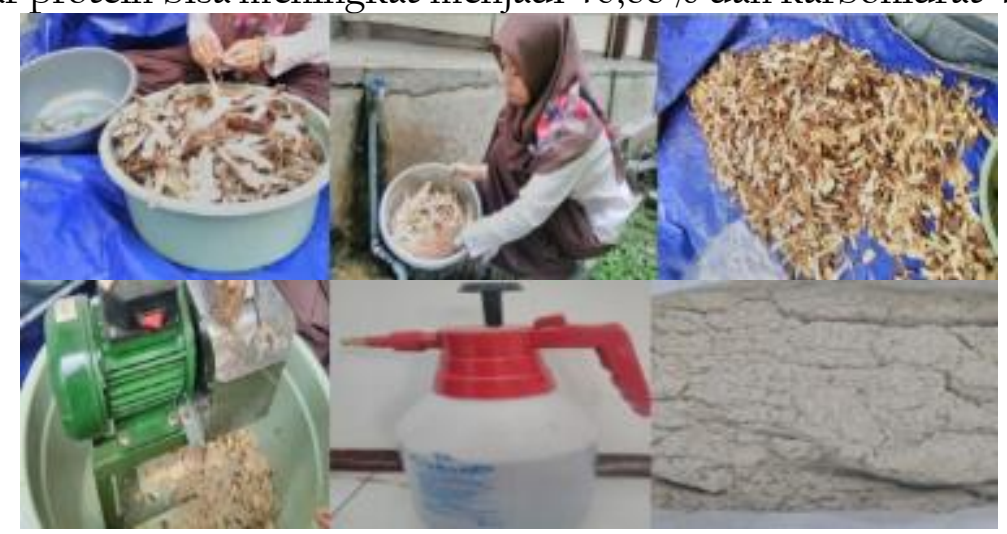

Gambar 6 Proses fermentasi kulit singkong

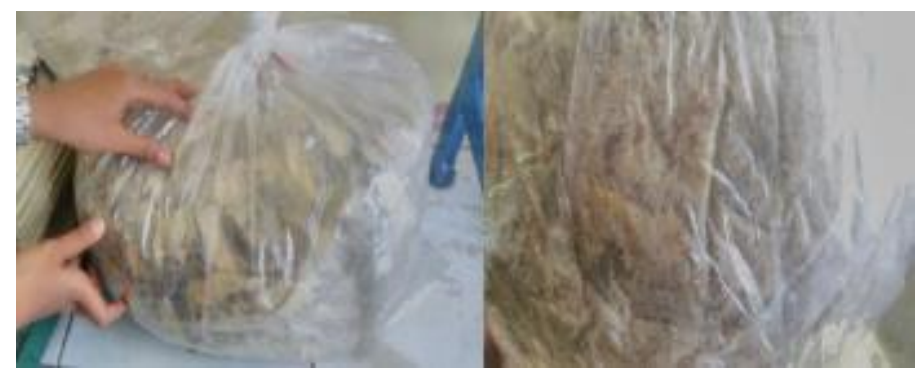

Gambar 7 Kulit singkong fermentasi

Hasil kegiatan pelatihan ini, menunjukkan bahwa IRT mampu melakukan fermentasi kulit singkong sebagai bahan baku pakan ternak. Kendala yang dihadapi dalam melakukan fermentasi ini adalah IRT membutuhkan waktu dalam pengolahan. Produk yang dihasilkan kulit singkong fermentasi kasar dapat diberikan pada hewan ruminansia seperti sapi, kambing, domba dan kerbau, harga untuk produk ini berkisar Rp. 1.000/kg. Kulit singkong fermentasi halus dapat langsung diberikan pada ayam kampung dan bebek, harga untuk produk ini berkisar Rp.2000/kg.
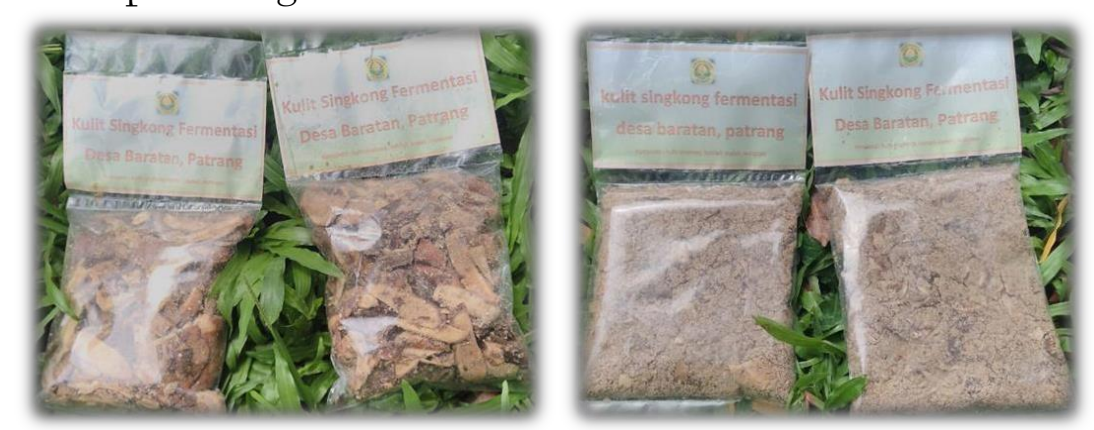

Gambar 8 Produk kemasan kulit singkong fermentasi kasar dan halus

\subsection{Penyuluhan mengenai cara menformulasi pakan ayam pedaging}

Kegiatan penyuluhan ini diawali dengan pemberian pengetahuan kepada IRT mengenai beberapa macam bahan pakan yang dapat digunakan sebagai pakan ternak. IRT 
juga diperkenalkan cara mencampur ransum dan menghitungnya sehingga ransum yang dibuat memiliki nutrien yang lengkap dan dapat digunakan sebagai pakan ternak. Kulit singkong memiliki peluang untuk digunakan sebagai pakan ternak unggas (Hidayat, 2009). Ketersediaan kulit singkong yang melimpah di Desa Baratan berpotensi menjadi penyedia bahan baku utama dari ransum unggas.

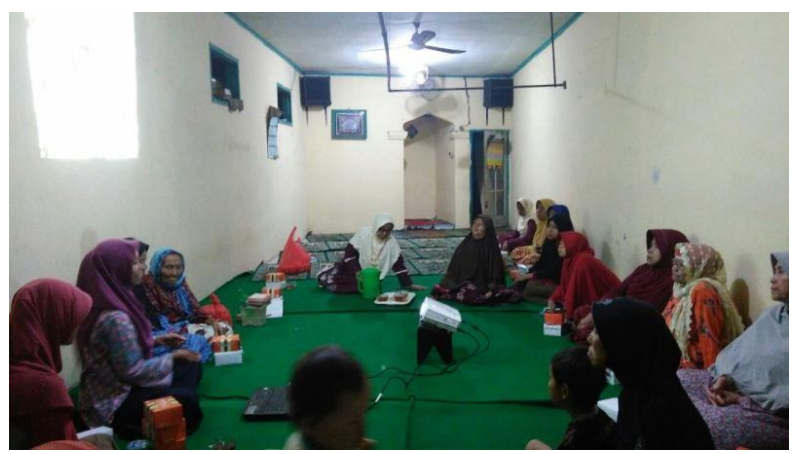

Gambar 9 Pelatihan formulasi ransum pakan ayam pedaging Kebutuhan Nutrien Ayam Tabel l. Kebutuhan nutrien pakan ternak ayam pedaging

\begin{tabular}{|c|c|c|}
\hline Nutrisi & $\begin{array}{l}\text { Starter } \\
(0-3 \text { minggu })\end{array}$ & $\begin{array}{l}\text { Finisher } \\
(3-6 \mathrm{minggu})\end{array}$ \\
\hline Kadar air (\%) & 10,00 (maks. 14,0) & 10,00 (maks. 14,0) \\
\hline Protein (\%) & $23(\min .19,0)$ & $20(\min .18,0)$ \\
\hline Energi (Kkal EM/kg) & $3200(\min .2900)$ & $3200(\min .2900)$ \\
\hline Lisin $(\%)$ & $1,10(\min .1,10)$ & $1,00(\min .0,90)$ \\
\hline Metionin (\%) & $0,50(\min .0,40)$ & $0,38$ (min. 0,30$)$ \\
\hline Metionin + sistin (\%) & $0,90(\min .0,60)$ & $0,72(\min .0,50)$ \\
\hline $\mathrm{Ca}(\%)$ & $1,00(0,90-1,20)$ & $0,90(0,90-1,20)$ \\
\hline P tersedia (\%) & $0,45(\min .0,40)$ & $0,35$ (min. 0,40$)$ \\
\hline
\end{tabular}

Sumber: NRC (1994); SNI (2008)

Melakukan penyuluhan mengenai cara menformulasi pakan ayam pedaging yang berasal dari hasil fermentasi kulit singkong. Kegiatan ini diharapkan IRT mampu melakukan pengolahan hasil fermentasi kulit singkong menjadi pakan pellet ayam pedaging dengan mencampurkan beberapa bahan baku pakan yang lain dengan harga terjangkau dan mudah dicari serta dapat diberikan pada ternak.

3.5 Praktek mengolah bahan baku pakan dengan bahan utama hasil fermentasi kulit singkong menjadi pellet pakan ayam pedaging.

Kegiatan diawali dengan pencampuran beberapa bahan baku pakan utamanya hasil fermentasi kulit singkong. Melakukan percontohan secara terstruktur dan praktek mengolah bahan baku pakan dengan bahan utama hasil fermentasi kulit singkong menjadi pellet pakan ayam pedaging. Sedangkan ayam broiler perlu diberikan formulasi ransum untuk memenuhi kebutuhan nutrien sesuai yang dibutuhkan dan dibentuk menjadi pellet. Membuat ransum ayam pedaging dengan persentase bahan pakan pada tabel 2:

Tabel 2. Formulasi ransum ayam pedaging

\begin{tabular}{|c|c|}
\hline Bahan & Persentase (\%) \\
\hline Dedak & 8,5 \\
\hline Jagung & 39 \\
\hline
\end{tabular}


Bungkil Kedelai

Tepung Ikan

Bungkil Kelapa

Fermentasi kulit singkong

Premix

Total
15,5

13,3

6,5

15

0,2

100

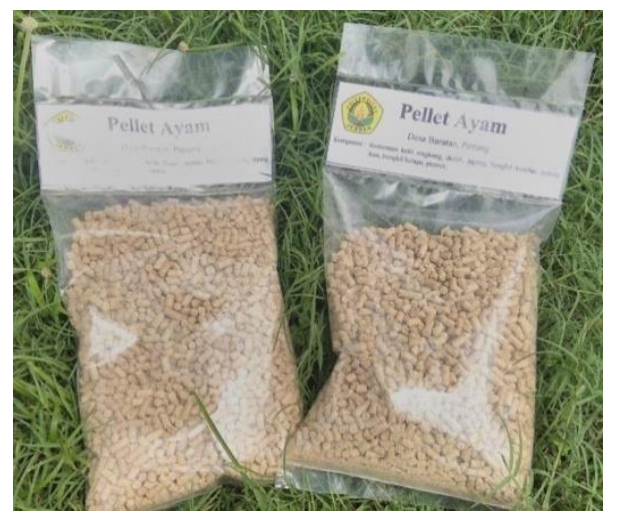

Gambar 10 Produk kemasan pellet kulit singkong

3.6 Pembuatan buku petunjuk cara fermentasi kulit singkong, formulasi ransum hingga pembuatan pellet pakan ayam pedaging.

Kegiatan pengabdian juga membuat buku petunjuk tentang Cara Fermentasi kulit singkong, formulasi ransum ternak dan pembuatan pellet pakan ayam pedaging. Buku ini terdiri dari beberapa bab yaitu Bab l. Fermentasi kulit singkong, dalam bab ini dijelaskan mengenai langkah-langkah yang dilakukan dalam pembuatan kulit singkong fermentasi. Bab 2. Bahan baku pakan ayam pedaging dan teknik formulasi ransum ayam pedaging, dalam bab ini dijelaskan macam-macam bahan baku pakan yang biasa digunakan dalam pembuatan pakan ayam pedaging dan teknik formulasi ransum yang mudah untuk menyusun nutrian pakan ayam pedaging. Bab 3. Cara pembuatan pakan pellet ayam pedaging dengan bahan baku utama kulit singong fermentasi.

Buku petunjuk ini dibuat dengan tujuan untuk membantu IRT agar lebih mudah dalam memahami langkah pembuatan pakan pellet ayam pedaging dengan bahan baku utama limbah kulit singkong mulai dari langkah awal pembuatan kulit singkong fermentasi, penyusunan ransum hingga pengolahan menjadi pellet pakan ayam pedaging ketika IRT membutuhkan referensi atau tutorial jika nantinya kegiatan ini selesai dilakukan. Berikut ini adalah cover depan dan belakang buku panduan tersebut (Gambar ll). 


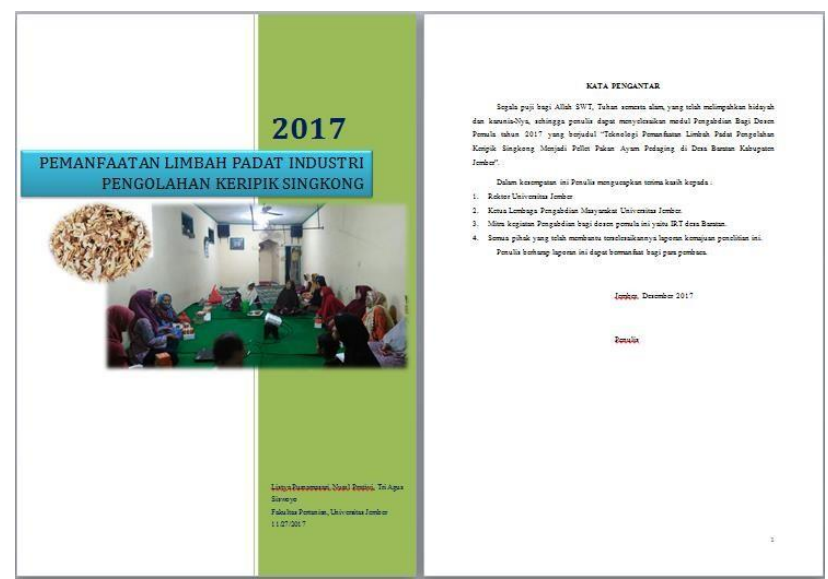

Gambar 11 Buku petunjuk cara pengolahan limbah kulit singkong menjadi pellet pakan ayam pedaging

\section{KESIMPULAN}

Berdasarkan hasil kegiatan pengabdian bagi dosen pemula mengenai Teknologi Pemanfaatan Limbah Padat Pengolahan Keripik Singkong Menjadi Pellet Pakan Ayam Pedaging di Desa Baratan Kabupaten Jember, dapat disimpulkan beberapa hal yaitu IRT keripik singkong mampu mengolah limbah padat berupa kulit singkong menjadi pakan fermentasi yang langsung dapat diberikan kepada peternak kambing, domba maupun sapi (ruminansia) dan mampu mengolah hasil kulit singkong fermentasi menjadi pakan pellet ayam pedaging dengan memformulasikannya dengan bahan baku pakan yang lain.

\section{DAFTAR PUSTAKA}

Akhadiarto, S. 2010. Pengaruh pemanfaatan limbah kulit singkong dalam pembuatan pelet ransum unggas. J. Tek. Ling vol 11 (1) : 127 - 138.

Amri, E dan P. Pratiwi. 2014. Pembuatan MOCAF (Modified cassava flour) dengan proses fermentasi menggunakan ragi yang berbeda. Jurnal pelangi vol 6 (171 - 179).

Bradbury, J. H., dan J. Denton. 2010. Rapid wetting method to reduce cyanogen content of cassava flour. Food Chemistry. $121: 591-594$.

Budiarto. 2011. Opportunity of Modified Cassava Flour (MOCAF) as wheat flour substitute an alternative materials to support food security. Proceeding ISNAR C2FS 837.

Hidayat, C. 2009. Peluang penggunaan kulit singkong sebagai pakan unggas. seminar nasional teknologi peternakan dan veteriner.

National Research Council. 1994. Nutrient Requirements of Poultry Eighth Revised Edition. National Academy of Sciences. Washington, DC.

Richana, N., 2013. Mengenal potensi ubi kayu dan ubi jalar. Nuansa Cendikia, Bandung.

Sandi, S., 2012. Niai nutrisi kulit singkong yang mendapat perlakuan bahan pengawet selama penyimpanan. Jurnal Penelitian Sains vol 15 no. 2 (89-92). 